DOI: https://doi.org/10.35961/jppmkepri.v1i1.191

\title{
Optimalisasi Penggunaan E-Learning dalam Pelajaran Bahasa Inggris di SMP IT Almadinah di Kota Tanjungpinang
}

\author{
Ferri Yonantha ${ }^{1 *}$, Muslena Layla ${ }^{2}$, Taqiyuddin ${ }^{3}$, Nahrim Ajmain ${ }^{4}$, Firdaus $^{5}$ \\ 1, 2, 3, 4, 5 STAIN Sultan Abdurrahman Kepulauan Riau, Bintan, Kepulauan Riau, 29123, Indonesia \\ * ferri.yonantha@stainkepri.ac.id
}

\begin{abstract}
Abstrak
Pembelajaran daring atau online learning belum maksimal diterapkan di SMP IT Al Madinah dalam pembelajaran bahasa Inggris dengan tidak melibatkan adanya interaksi langsung selama pembelajaran online yang menggunakan aplikasi Google Classroom dan Whatsapp. Oleh karena itu, pengabdian kepada masyarakat ini dilakukan yang berjujuan untuk mengoptimalisasikan penggunaan E-Learning dalam pengajaran Bahasa Inggris melalui aplikasi Zoom Clouds Meeting sebagai pelayanan yang dilakukan oleh tim pengajar mata pelajaran Bahasa Inggris di sekolah SMP IT Al Madinah selama pembelajaran dari rumah (school from home) yang disebabkan oleh pandemi Covid-19. Total responden pada penelitian ini adalah sebanyak 2 (dua) orang guru Bahasa Inggris, 32 (tiga puluh dua) siswa perempuan dan 32 (tiga puluh dua) siswa laki-laki. Metode pengabdian kepada masyarakat yang dilakukan adalah Participatory. Langkah- langkah pengabdian ini dilakukan melalui 3 (tiga) tahapan: 1. Persiapan. 2. Implementasi dan 3. Evaluasi. Hal ini juga mencakup satu pertemuan untuk observasi dan pengumpulan data, dua pertemuan untuk mengajar dengan menggunakan aplikasi Zoom Clouds Meeting dan kuisioner dibagikan kepada siswa untuk menelusuri tingkat kepuasan siswa menggunakan Zoom Clouds Meeting selama proses belajar. Hasilnya ditemukan bahwa kebanyakan siswa termotivasi belajar menggunakan aplikasi Zoom Clouds Meeting karena mereka mampu berkomunikasi secara langsung kepada gurunya selama proses belajar. Oleh karena itu, dibuktikan dengan 92,4\% siswa perempuan dan $82,6 \%$ siswa laki-laki setuju menggunakan E-Learning aplikasi Zoom Clouds Meeting pada mata pelajaran Bahasa Inggris.
\end{abstract}

Kata kunci: Covid-19; Optimal; Aplikasi Zoom Clouds Meeting

\begin{abstract}
The implementation of online learning was not optimally implemented at Almadinah Junior High School Tanjungpinang in English Subject by not having direct interaction between the teacher and students during the class which was taught through Google Classroom and Whatsapp applications. Therefore, this community service was carried out to optimize the use of E-Learning in learning English through Zoom Clouds Meeting Application as a community service done
\end{abstract}


by the Department of English Education team at Almadinah Islamic Junior High School during School from Home caused by COVID-19 pandemic. The total respondents in this study were 2 English teachers, 32 female students, and 32 male students. The method used was a Participatory Method. It was carried out through 3 stages: 1) Preparation, 2) Implementation, and 3) Evaluation. It also included one meeting for observation and data collection, two meetings of teaching by using zoom clouds meeting application, and questionnaire spread to investigate students' satisfaction about the online learning. Results found that most of students were motivated to learn through zoom clouds meeting application because they were able to communicate directly to the teachers during the lesson. Thus, it was proved by the total 92,4\% of female students and 82,6\% of male students agreed to use this application as an E-learning platform for English Subject.

Keywords: Covid19; optimization; Zoom Clouds Meeting Application

\section{Pendahuluan}

Corona Virus Disease 2009 atau Covid-19 telah menjadi pandemi di berbagai belahan dunia. Dalam dunia pendidikan hal ini berdampak sangat besar. Dikarenakan penyebaran wabah ini sudah sangat meluas, di Indonesia terkhusus Provinsi Kepulauan Riau, sekolah-sekolah telah dialihkan dari pembelajaran di kelas menjadi pembelajaran di rumah. Hal ini berlaku sejak pemberlakuan Surat Edaran Walikota Tanjungpinang Nomor 442.3/362/4.2.03/2020, tertanggal 16 Maret 2020 tentang pembelajaran peserta didik dari PAUD sampai dengan SMA dilakukan di rumah dimulai 17 sampai 24 Maret 2020. Kemudian, pembelajaran di rumah ini diperpanjang melalui surat edaran berikutnya. Melalui Surat Edaran Walikota Tanjungpinang Nomor 442.1/424/5.3.01/2020 tentang perpanjangan pelaksanaan kegiatan belajar dari rumah dalam masa tanggap darurat penyebaran Covid-19 di Kota Tanjungpinang yaitu dimulai dari tanggal 1 April sampai dengan 21 April 2020. Perkembangan selanjutnya akan disesuaikan dengan kondisi berikutnya.

Pembelajaran yang dilakukan dari rumah memiliki keterbatasan terkait penjabaran dan pengembangan aktifitas. Sekolah dan guru tidak serta-merta memberikan buku pegangan untuk dibaca dan dipahami sendiri oleh peserta didik. Pembelajaran berbasis elektronik (E-Learning) menjadi solusi pada saat ini untuk melaksanakan kegiatan pembelajaran seiring dengan sudah begitu majunya perkembangan teknologi dan ICT (Information Communication and Technology) saat ini. Perubahan dari sebelumnya fokus terhadap pengajaran (teacing) menjadi lebih fokus terhadap pembelajaran (learning) merupakan manifestasi atas kemajuan teknologi informasi dan komunikasi dalam dunia Pendidikan. Tren pengajaran (teacing) menempatkan guru sebagai satu-satunya komunikator aktif menggunakan Teknologi Informasi dan Komunikasi (TIK) dalam proses belajar mengajar, kini telah mengalami perubahan besar; guru (pendidik/pengajar) dan siswa (pelajar) telah ditempatkan dalam posisi yang sama-sama aktif menggunakan teknologi dan media dalam proses pembelajaran (learning).

Semua sekolah telah mengembangkan proses pembelajaran berbasis E-Learning untuk wilayah Kota Tanjungpinang. Sekolah Menengah Pertama Islam Terpadu (SMP-IT) yang ada di Kota Tanjungpinang, khususnya SMP IT Al Madinah Kota Tanjungpinang juga telah menerapkan pembelajaran berbasis $E$ Learning selama masa Covid-19 sampai saat ini. Berbagai model E-Learning ditetapkan oleh sekolah. SMP IT Al Madinah Kota Tanjungpinang secara kompak menetapkan penggunaan Google Classroom dan aplikasi Whatsapp sebagai media pembelajaran berbasis E-Learning. Yang menjadi permasalahan saat ini adalah ketika pembelajaran berbasis E-Learning tersebut tidak dioptimalkan dengan baik dengan hanya membagikan tugas secara online dari guru kepada peserta didik. 
Pelajaran Bahasa Inggris menekankan pengintegrasian antara penguasaan empat keahlian yang mencakup keahlian mendengarkan (listening), berbicara (speaking), membaca (reading), dan menulis (writing). Namun, sejak pemberlakuan pembelajaran di rumah, seakan-akan guru hanya menekankan kepada penguasaan keahlian membaca (reading) siswa saja. Siswa diberikan materi melalui buku pegangan untuk dibaca dan dikuasai sendiri, setelah itu guru memberikan latihan dan kuis melalui Google Form dimana siswa hanya perlu menjawab soal yang diberikan dalam bentuk multiple choise dan essay. Pembelajaran berbasis E-Learning ini pun menjadi kurang efektif dalam pembelajaran Bahasa Inggris. Kegiatan yang dilakukan selama pembelajaran berbasis E-Learning bisa dilakukan dengan variatif menggunakan berbagai media pembelajaran berbasis online sehingga pembelajaran menjadi lebih menarik dan target pembelajaran dapat tercapai secara efektif dan efisien. Oleh karena itu, kegiatan Pengabdian Kepada Masyarakat ini dilakukan oleh Tim Penyusun, agar SMP IT Al Madinah Kota Tanjungpinang dapat mengoptimalisasi pembelajaran Bahasa Inggris berbasi E- Learning yang telah dilakukan selama Covid-19 dengan menggunakan aplikasi Zoom Clouds Meeting.

\section{Metode}

Metode Participatory Action Research digunakan dalam kegiatan Pengabdian Kepada Masyarakat ini. Metode riset ini dilaksanakan secara partisipatif di antara warga masyarakat dalam suatu komunitas aras bawah yang semangatnya untuk mendorong terjadinya aksi-aksi transformative melakukan pembebasan masyarakat dari belenggu ideologi dan relasi kekuasaan (perubahan kondisi hidup yang lebih baik.

Prinsip-prinsip pada metode participatory action research juga diterapkan dalam keguatan Pengabdian Kepada Masyarakat ini. Prinsip pertama adalah prinsip partisipasi yang mengharuskan guru dan siswa melaksanakan kegiatan pembelajaran melalui Zoom Zlouds Meeting separtisipatif mungkin. Selanjutnya prinsip kedua yaitu prinsip orientasi aksi. Prinsip ini menuntut seluruh kegiatan pembelajaran melalui Zoom Clouds Meeting dapat mengarahkan guru dan siswa untuk agar kegiatan pembelajaran online menjadi lebih efektif dan efisien. Prinsip triangulasi adalah prinsip ketiga yang mengharuskan digunakannya berbagai sudut pandang, metode, alat kerja yang berbeda untuk memahami situasi yang sama dalam mengoptimalkan pembelajaran online. Prinsip terakhir adalah prinsip luwes dan fleksibel. Prinsip ini mengharuskan pelaksanaan dilakukan dengan perencanaan yang matang, cermat dan hati-hati. Antara peneliti, guru dan siswa harus dapat bersikap luwes terhadap perubahan situasi yang mungkin terjadi.

Langkah-langkah pendampingan pada penelitian participatory action research ada tiga tahapan yang dilakukan dalam penelitian ini, yaitu:

1. Preparation (persiapan). Tahapan persiapan ini dilakukan untuk mengetahui kondisi riil guru Bahasa Inggris yang ada di SMP IT Al Madinah dengan menggunakan analisis SWOT (strength, weaknesses, opporinities dan threats). Dengan menganalisis permasalahan yang dihadapi guru Bahasa Inggris SMP IT Al Madinah peneliti menginformasikan dan mendampingi guru tersebut dalam mengoptimalisasikan apa saja kekuatan, kelemahan, peluang dan ancaman menggunakan $E$ Learning pada proses pembelajaran.

2. Implementation (implementasi). Setelah proses persiapan telah dilakukan, guru Bahasa Inggris SMP IT Al Madinah membuat Tindakan atau mengimplementasikan rencana yang sudah dibuat dan dibantu oleh peneliti.

3. Evaluation atau reflection. Evaluasi dilakukan untuk mengetahui keberhasilan penggunaan $E$ Learning dalam proses pembelajaran baik itu guru yang dievaluasi maupun siswa tersebut, dan usaha-usaha yang telah dilakukan dalam menghadapi pembelajaran dengan menggunakan $E$ Learning pada masa pandemi Covid-19 tersebut dievaluasi dan direfleksi baik kekurangan, kelemahan, dan keberhasilan strategi dan metode dalam memecahkan permasalahan yang dihadapi guru Bahasa Inggris SMP IT Al Madinah. 
Dalam hal ini, Tim Penyusun berperan sebagai researcher yang melibatkan partisipasi 2 orang Guru Bahasa Inggris, 32 siswa ikhwan dan 32 siswa akhwat. Adapun transformasi yang dimaksud dalam kegiatan ini adalah optimalisasi penggunaan E-Learning pada pelajaran Bahasa Inggris di SMP IT Al Madinah Kota Tanjungpinang melalui aplikasi Zoom Clouds Meeting.

Program pengabdian masyarakat yang telah dilakukan ini diperuntukkan guna memberikan opsi $E$ Learning yang lebih baik yang dapat dipergunakan oleh SMP IT Al Madinah. Kegiatan ini berupa pendampingan terhadap guru Bahaas Inggris SMP IT Al Madinah dalam memanfaatkan aplikasi Zoom Clouds Meeting sebagai media E-Learning selama school from home yang diakibatkan oleh pandemi Covid19 sehingga pembelajaran Bahasa Inggris tetap dapat berjalan dengan melibatkan interaksi dan komunikasi aktif antarsiswa dan guru. Demi tercapainya tujuan ini, kegiatan pengabdian yang dilakukan, adalah: 1) Observasi awal tentang kegiatan pembelajaran berbasis E-Learning di SMP IT Al Madinah Kota Tanjungpinang, 2) Pendampingan yang dilakukan Tim Penyusun kepada Guru Bahasa Inggris untuk mempersiapkan pengajaran Bahasa Inggris menggunakan aplikasi Zoom Clouds Meeting, 3) Pendampingan pengajaran yang dilakukan selama 2 pertemuan dimana pada pertemuan pertama guru dibantu tim sebagai host meeting, dan di pertemuan kedua guru secara mandiri menjadi host meeting pada kelas daringnya menggunakan aplikasi Zoom Clouds Meeting yang setiap sesinya berdurasi 40 menit, 4) Demi mengetahui respon peserta didik tentang penggunaan aplikasi Zoom Clouds Meeting sebagai media pembelajaran berbasis E-Learning, tim penyusun menyebarkan kuisioner penilaian kepuasan peserta didik terhadap pembelajaran Bahasa Inggris berbasis E-Learning menggunakan aplikasi Zoom Clouds Meeting. Adapun indikator keberhasilan program ini dapat dilihat dari tingkat kepuasan peserta didik terhadap setiap butir pertanyaan seperti "Sangat Setuju", "Setuju", "Ragu-Ragu", "Tidak Setuju” dan "Sangat Tidak Setuju”.

\section{Hasil dan Pembahasan}

Hasil

Kegiatan pengabdian kepada masyarakat yang dilakukan oleh Tim penyusun dilakukan dalam 3 tahap, yaitu persiapan, pelaksanaan, dan evaluasi yang dapat dipaparkan sebagai berikut.

1. Persiapan

Pada tahapan ini, tim melakukan observasi awal dengan turun ke lapangan sekaligus meminta perizinan kepala SMP IT Al Madinah untuk melaksanakan kegiatan pengabdian. Wawancara dipilih sebagai metode pengumpulan data awal terhadap 2 orang Guru Bahasa Inggris SMP IT Al Madinah. Setelah itu tim menjelaskan penggunaan aplikasi Zoom Clouds Meeting sebagai media E-Learning. Kegiatan pendampingan pada tahapan ini mencakup tentang persiapan perangkat pembelajaran seperti Lesson Plan dan Power Point Presentation. Kegiatan ini dilakukan secara tatap muka dan virtual menggunakan fitur chat Whatsapp.

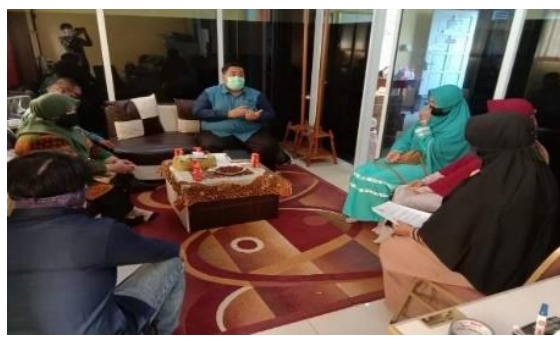

Gambar 1. Observasi Awal di SMP IT Al Madinah Kota Tanjungpinang

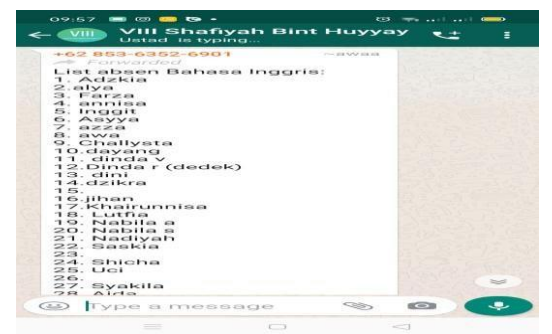

Gambar 2. Observasi Penggunaan e-Learnig yang telah ada di SMP IT Almadinah menggunakan google classroom dan whatsapp 


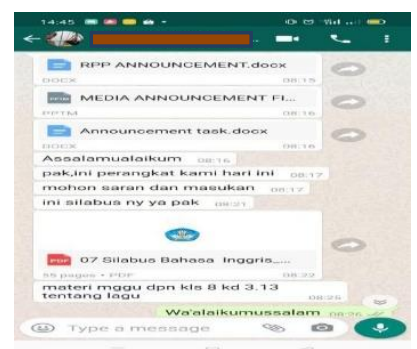

Gambar 3. Persiapan Perangkat Pembelajaran

2. Pelaksanaan

Pada tahapan ini, tim mengadakan dua pertemuan pendampingan. Pada pertemuan pertama tim menjadi host Zoom Clouds Meeting membantu guru meng-invite seluruh peserta didik yang terlibat. Pada pertemuan kedua, guru Bahasa Inggris telah secara aktif menjadi host pada kelas daringnya.

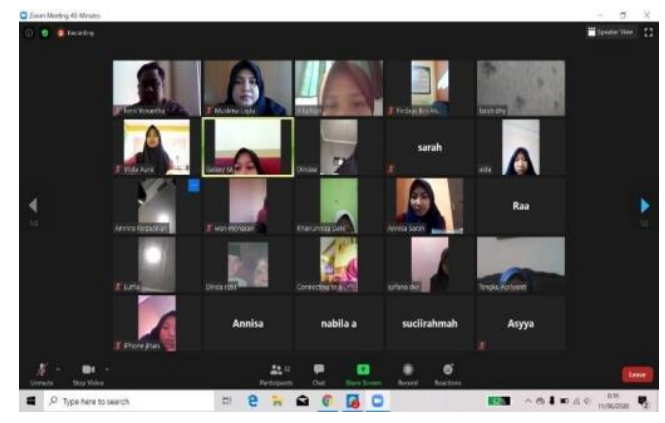

Gambar 4. Pertemuan Pertama Pembelajaran Bahasa Inggris Menggunakan Aplikasi Zoom Clouds Meeting

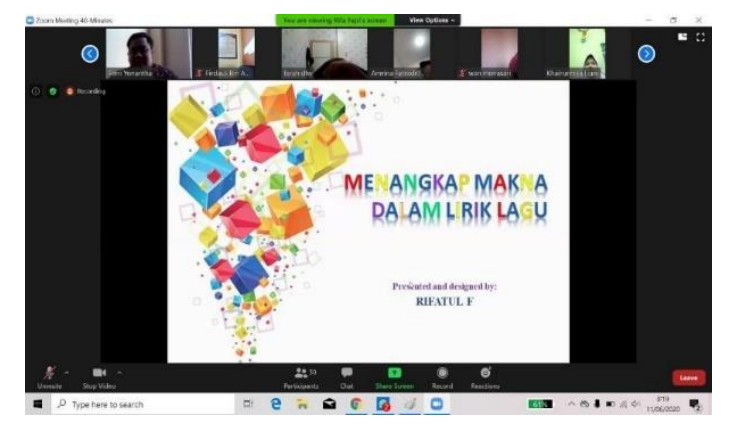

Gambar 5. Pertemuan Kedua dimana Guru menjadi Host Mandiri menggunakan aplikasi Zoom Clouds Meeting pada kelas Akhwat

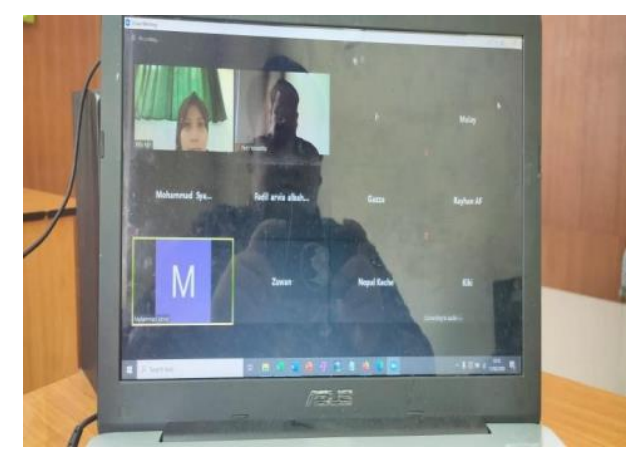

Gambar 6. Pertemuan Kedua dimana Guru menjadi Host Mandiri menggunakan aplikasi Zoom Clouds Meeting pada kelas Ikhwan

Selama tahapan pelaksanaan ini, tim mendampingi guru Bahasa Inggris SMP IT Al Madinah selama pembelajaran Bahasa Inggris berlangsung menggunakan aplikasi Zoom Clouds Meeting. Aspek yang menjadi titik fokus adalah teknis dan interaksi guru dan siswa selama proses pembelajaran Bahasa Inggris. Guru bisa menjelaskan materi secara langsung dan berinteraksi langsung kepada siswa. 
3. Evaluasi

Dalam tahapan ini, penyusun membagikan kuisioner penilaian kepuasan peserta didik terhadap penggunaan aplikasi Zoom Clouds Meeting pada pelajaran Bahasa Inggris. Kuisioner ini dibuat menggunakan Google Form yang disebarkan melalui Whatsapp kepada peserta didik.

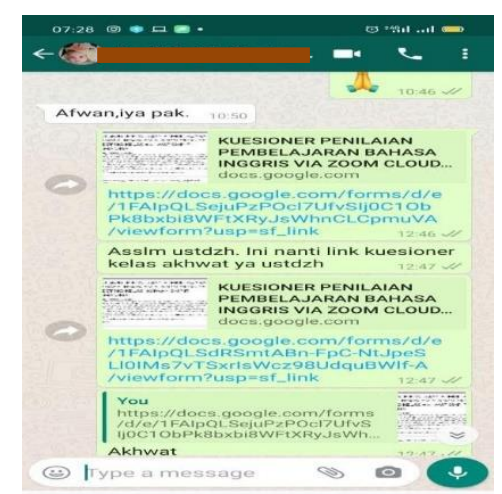

Gambar 7. Penyebaran Kuesioner Kepuasan Siswa

Adapun kuesioner ini memiliki 7 pernyataan. Hasil respons yang diberikan oleh siswa dapat dilihat sebagai berikut:

Tabel 1

Tingkat Penilaian Pembelajaran Bahasa Inggris Via Zoom Clouds Meeting Kelas Akhwat (32 Responden) SMP IT Al Madinah

\begin{tabular}{|c|c|c|c|c|c|}
\hline \multirow[b]{2}{*}{ Pernyataan } & \multicolumn{5}{|c|}{ Persentase $(\%)$} \\
\hline & 1 & 2 & 3 & 4 & 5 \\
\hline $\begin{array}{l}\text { 1. Online class menggunakan aplikasi Zoom Clouds Meeting } \\
\text { menjadi lebih menarik }\end{array}$ & 53.1 & 34.4 & 12.5 & 0 & 0 \\
\hline $\begin{array}{l}\text { 2. Materi yang dijelaskan menjadi lebih mudah dipahami melalui } \\
\text { aplikasi Zoom Clouds Meeting }\end{array}$ & 46.9 & 40.6 & 12.5 & 0 & 0 \\
\hline 3. Siswa bisa langsung bertanya tentang materi yang tidak dipahami & 50 & 46.9 & 3.1 & 0 & 0 \\
\hline $\begin{array}{l}\text { 4. Siswa bisa berkomunikasi secara langsung dalam bahasa Inggris } \\
\text { bersama guru dan teman melalui aplikasi Zoom Clouds Meeting }\end{array}$ & 46.9 & 46.9 & 6.3 & 0 & 0 \\
\hline $\begin{array}{l}\text { 5. Guru dapat menyajikan materi pembelajaran melalui aplikasi } \\
\text { Zoom Clouds Meeting }\end{array}$ & 46.9 & 46.9 & 3.1 & 3.1 & 0 \\
\hline $\begin{array}{l}\text { 6. Siswa berkesempatan untuk lebih aktif selama online learning } \\
\text { berlangsung }\end{array}$ & 46.9 & 46.9 & 6.3 & 0 & 0 \\
\hline $\begin{array}{l}\text { 7. Online learning melalui aplikasi Zoom Clouds Meeting bisa } \\
\text { dilakukan dimanapun }\end{array}$ & 59.4 & 34.4 & 6.3 & 0 & 0 \\
\hline Rata - rata & $\mathbf{5 0 , 0}$ & 42,4 & 7,2 & 0,4 & $\mathbf{0}$ \\
\hline
\end{tabular}

Keterangan :

$1=$ Sangat Setuju 
$2=$ Setuju

$3=$ Ragu-ragu

$4=$ Tidak Setuju

$5=$ Sangat Tidak setuju

Tabel 2

Tingkat Penilaian Pembelajaran Bahasa Inggris Via Zoom Clouds Meeting Kelas Ikhwan (32 Responden) SMP IT Al Madinah

\begin{tabular}{|c|c|c|c|c|c|c|}
\hline \multirow{2}{*}{ No } & \multirow{2}{*}{ Pernyataan } & \multicolumn{5}{|c|}{ Persentase (\%) } \\
\hline & & 1 & 2 & 3 & 4 & 5 \\
\hline 1 & $\begin{array}{l}\text { Online class menggunakan aplikasi Zoom Clouds Meeting menjadi } \\
\text { lebih menarik }\end{array}$ & 53.1 & 31.3 & 9.4 & 0 & 6.3 \\
\hline 2 & $\begin{array}{l}\text { Materi yang dijelaskan menjadi lebih mudah dipahami melalui } \\
\text { aplikasi Zoom Clouds Meeting }\end{array}$ & 43.8 & 37.5 & 15.6 & 3.1 & 0 \\
\hline 3 & Siswa bisa langsung bertanya tentang materi yang tidak dipahami & 53.1 & 37.5 & 9.4 & 0 & 0 \\
\hline 4 & $\begin{array}{l}\text { Siswa bisa berkomunikası secara langsung dalam banasa Inggrıs } \\
\text { bersama guru dan teman melalui aplikasi Zoom Clouds Meeting }\end{array}$ & 46.9 & 46.9 & 6.3 & 0 & 0 \\
\hline 5 & $\begin{array}{l}\text { Guru dapat menyajikan materi pembelajaran melalui aplikasi Zoom } \\
\text { Clouds Meeting }\end{array}$ & 43.8 & 43.8 & 12.4 & 0 & 0 \\
\hline 6 & $\begin{array}{l}\text { Siswa berkesempatan untuk lebih aktif selama online learning } \\
\text { berlangsung }\end{array}$ & 34.4 & 40.6 & 25 & 0 & 0 \\
\hline 7 & $\begin{array}{l}\text { Online learning melalui aplikasi Zoom Clouds Meeting bisa } \\
\text { dilakukan dimanapun }\end{array}$ & 46.9 & 18.8 & 15.6 & $\begin{array}{c}15 . \\
6\end{array}$ & 3.1 \\
\hline & Rata - rata & 46,0 & 36,6 & 13,4 & 2,7 & 1,3 \\
\hline
\end{tabular}

Keterangan :

$1=$ Sangat Setuju

$2=$ Setuju

3 = Ragu-ragu

$4=$ Tidak Setuju

$5=$ Sangat Tidak setuju

\section{Pembahasan}

Berdasarkan hasil di atas, dapat dilihat ketercapaian indikator pendampingan yaitu:

1. Siswa merasa pembelajaran berbasis E-Learning menggunakan Zoom Clouds Meeting menjadi lebih menarik terbukti dengan jumlah persentase siswa Akhwat yang setuju dan sangat setuju yaitu sebesar $89,5 \%$ dari total 32 responden, sedangkan pada Ikhwan sebesar 84,4\% dari total 32 responden. 
2. Siswa merasa materi pelajaran lebih mudah dipahami menggunakan Zoom Clouds Meeting terbukti dengan jumlah persentase siswa Akhwat yang setuju dan sangat setuju yaitu sebesar 87,5\% dari total 32 responden, sedangkan pada Ikhwan sebesar $81,3 \%$ dari total 32 responden.

3. Siswa bisa langsung bertanya menggunakan Zoom Clouds Meeting selama pembelajaran berlangsung dibuktikan dengan jumlah persentase siswa Akhwat yang setuju dan sangat setuju yaitu sebesar 96.9\% dari total 32 responden, sedangkan pada Ikhwan sebesar $90.6 \%$ dari total 32 responden.

4. Siswa bisa berkomunikasi langsung dalam Bahasa Inggris bersama guru dan temannya menggunakan Zoom Clouds Meeting selama pembelajaran berlangsung dibuktikan dengan jumlah persentase siswa Akhwat yang setuju dan sangat setuju yaitu sebesar 93,8\% dari total 32 responden, dan siswa Ikhwan juga sebesar $93.8 \%$ dari total 32 responden.

5. Materi yang diajarkan guru dapat langsung ditampilkan menggunakan Zoom Clouds Meeting selama pembelajaran berlangsung dibuktikan dengan jumlah persentase siswa Akhwat yang setuju dan sangat setuju yaitu sebesar 93,8\% dari total 32 responden, sedangkan pada Ikhwan sebesar $85 \%$ dari total 32 responden.

6. Siswa bisa berkesempatan lebih aktif selama pembelajaran berlangsung menggunakan Zoom Clouds Meeting dibuktikan dengan jumlah persentase siswa Akhwat yang setuju dan sangat setuju yaitu sebesar 96.9\% dari total 32 responden, sedangkan pada Ikhwan sebesar $90.6 \%$ dari total 32 responden.

7. Siswa menyepakati bahwa pembelajaran menggunakan aplikasi ini bisa dilakukan dimanapun. Sejumlah 93.8\% dari kelas Akhwat dan 65,7\% dari kelas Ikhwan menyetujuinya.

8. Kendala yang dihadapi oleh siswa dan guru selama pembelajaran Bahasa Inggris menggunakan aplikasi ini adalah terkait dengan kestabilan jaringan. Beberapa siswa mengalami gangguan jaringan sehingga tidak maksimal mendapatkan materi pelajaran dan mengikuti kegiatan pembelajaran

\section{Kesimpulan}

Kegiatan pendampingan ini memiliki kontribusi yang cukup baik dalam membantu guru Bahasa Inggris bahkan SMP IT Al Madinah Kota Tanjungpinang untuk memilih opsi E-Learning yang lain selain Google Classroom, yaitu salah satunya aplikasi Zoom Clouds Meeting. Melalui aplikasi ini siswa dapat berkomunikasi secara aktif dan guru mampu mengembangkan 4 skills utama dalam berbahasa Inggris secara terintegrasi. Hal ini yang tidak didapatkan melalui platform Google Classroom dan Whatssapp yang telah diterapkan sebelumnya. Namun demikian, masih ada beberapa poin yang harus diperbaiki dan mendapatkan perhatian, yaitu terkait kestabilan jaringan. Tim penyusun menyarankan agar guru dapat mengupload rekaman video pembelajaran via Zoom Clouds Meeting ke platform Youtube dan membagikan link video tersebut kepada siswa, sehingga siswa mampu mengulang-ulang video tersebut agar pemahaman menjadi lebih baik.

\section{Saran}

Kepada seluruh guru-guru yang mengampu mata pelajaran Bahasa Inggris agar selalu berinovasi dalam proses pembelajaran, banyak sekali aplikasi yang mensupport terkait pembelajaran seperti Google Classroom, Meet, Webex dan lain lain. Dan juga tidak mengesampingkan seluruh keahliah Bahasa Inggris seperti (Reading, Speaking, Listening dan Writing).

\section{Ucapan Terimakasih}

Pelaksanaan pengabdian masyarakat berbasis prodi pada tahun 2020 di Unit Kerja STAIN Sultan Abdurrahman Kepulauan Riau diumumkan kepada seluruh dosen baik itu yang PNS maupun yang NON- 
PNS, namum hanya beberapa dosen yang memenuhi kualifikasi pelaksanaan pengabdian tersebut. Untuk itu, ucapan terima kasih yang sebesar-sebesarnya kami sampaikan kepada seluruh pihak yang telah berpartisipasi atas terlaksananya pengabdian masyarakat ini, terutama kepada;

1. Bapak Dr. Muhammad Faisal, M.Ag. Selaku Ketua STAIN Sultan Abdurrahman Kepri beserta jajaran civitas akademika STAIN Sultan Abdurrahman Kepri.

2. Bapak D0ni Septian, M.IP dan Bapak Sukma Adi Perdana, M.Sc. selaku Kepala dan Sekretaris P3M STAIN Sultan Abdurrahman Kepulauan Riau

3. Bapak Zulkarnain Simbolon, S.HI selaku Kepala Sekolah SMP IT Almadinah Kota Tanjungpinang

4. Guru Bahasa Inggris SMP IT Almadinah Kota Tanjungpinang

5. Dosen homebase Prodi Tadris Bahasa Inggris yang terlibat dalam pengabdian masyarakat tahun 2020

\section{Referensi}

Asep H Suyanto. 2005. Pengembangan Kurikulum dan Pembelajaran. Universitas Terbuka.

Daryanto. 2013. Media Pembelajaran Perananya Sangat Penting Dalam Mencapai Tujuan Pembelajaran. Yogyakarta: Gava media.

Dewi Salma Prawiradilaga. 2013. Mozaik Teknologi Pendidikan E-learning. Jakarta: Prenadamedia Group. Effendy, Empy, Hartono Zhuang. 2005. E-Learning, Konsep dan Aplikasi. Yogyakarta: ANDI Kuswayanto, L. 2006: Mahir Berkomputer. Jakarta: Grafindo

Misbahul Munir \& Syafiul Muzid. Persepsi mahasiswa dalam e-learning sebagai aplikasi peningkatan kualitas pendidikan (studi kasus universitas islam indonesia) 2005. Diakses dari http://journal.uii.ac.id/index.php/Snati /article/viewFile/1301/1060. pada tanggal 4 April 2020, jam 16.20 WIB.

Munir. 2009. Pembelajaran Jarak Jauh. Bandung: Alfabeta.

R Poppy Yaniawati. 2010. E-Learning dan Alternatif Pembelajaran Kontemporer. Bandung: Arfino Raya.

Rory O'Brien. 1998. An Overview of The Methodological Approach of Action Research http://www.web.net/ robrien/papers/arfinal.html. diakses pada tanggal 23 Oktober 2020, jam 11.00

Setya Raharja, Dkk. 2011. "Model Pembelajaran Berbasis Management System dengan Pengembangan Software Moodle di SMA Negeri Kota Yogyakarta". Jurnal Kependidikan. Volume 4 (Nomor 1, Mei 2011).

Sutopo Ariesto Hadi. 2012. Teknologi Informasi dan Komunikasi dalam Pendidikan. Yogyakarta: Graha Ilmu.

Tafiardi. 2011. "Meningkatkan Mutu Pendidikan Melalui E-Learning”. Jurnal Pendidikan. (Nomor 1, Mei 2011). 